\title{
The Effect of Hypnobreastfeeding and Oxytocin Massage on Breastmilk Production in Postpartum
}

\author{
Authors \\ Putri Rahma Dini $^{1 *}$, Ari Suwondo ${ }^{2}$, Triana Sri Hardjanti ${ }^{1}$, Soeharyo Hadisaputro ${ }^{1}$, \\ Mardiyono ${ }^{1}$, Melyana Nurul Widyawati ${ }^{1}$ \\ ${ }^{1}$ Poltekkes Kemenkes Semarang, Semarang, Indonesia \\ ${ }^{2}$ Universitas Diponegoro, Semarang, Indonesia \\ *Corresponding Author \\ Putri Rahma Dini \\ Email: putrirahmadini91@gmail.com
}

\begin{abstract}
Background: Postpartum anxiety and lack of mother's knowledge about breastfeeding benefits leads to a lack of milk production.

Objective: to determine the effect of hypnobreastfeeding and oxytocin massage on breastmilk production in postpartum.

Methods: The design of this study used Quasi experiments with a pretest-posttest control group design. With purposive technique sampling, 52 women in postpartum were select from the population and divided in 4 groups. Group 1 given combination of hypnobreastfeeding and oxytocin massage, group 2 given hypnobreastfeeding, group 3 given oxytocin massage, and group 4 was the control group. To evaluate the difference of breastmilk production, one way anova test was used, and to evaluate the difference of breastmilk production before and after intervention in each group used repeated anova test, and for the effectiveness used Post hoc anova test.

Result: Hypnobreastfeeding and massage oxytocin significanly increased the breastmilk production in postpartum meanwhile the combination of hypnobreastfeeding and massage oxytocin have a greater result (79,10 $\mathrm{ml} / 2$ pumps / day), compare to hypnobreastfeeding group $(60,51 \mathrm{ml} / 2$ pumps / day), massage oxyitocin group (53, $32 \mathrm{ml} / 2$ times breast pump / day) and control group (42.18 ml / 2 times breast pump / day). And based on Post Hoc Test it can be concluded that breastmilk production in the combination group (hypnobreastfeeding and oxytocin massage) is greater than the other three groups.

Conclusion: Hypnobreastfeeding and oxytocin massage can increase breastmilk production in postpartum. Keywords: Hypnobreastfeeding, oxytocin massage, breastmilk, postpartum.
\end{abstract}

\section{Introduction}

Breastmilk is the best natural nutrient for infants with the most appropriate nutrient content for optimal growth ${ }^{[1]}$. UNICEF confirms that infants who given formula milk are likely to die in the first month of birth, and the chances of that is 25 times higher than in infants who exclusively breastfeeding ${ }^{[2]}$.

Breastfeeding early has a positive impact for both mother and baby. For babies, breastfeeding has an 
important role to support the growth, health, and survival of babies because breastmilk is rich in nutrients and antibodies. While for mothers, breastfeeding can reduce morbidity and mortality because the breastfeeding process will stimulate uterine contractions, thus reducing postpartum hemorrhage ${ }^{[3]}$.

Failure in the breastfeeding process is often caused by the emergence of several factors, including maternal factors, infant factors, psychological factors, health personnel factors, and socio-cultural factors ${ }^{[4]}$. Maternal factors that are problematic in breastfeeding are lack of breastmilk production. Lack of breastmilk production on the first day after delivery can be caused by lack of stimulation of the hormone oxytocin ${ }^{[5]}$.

The facts show that hormone oxytocin is affected by psychological conditions. Psychological mother preparation before breastfeeding is an important factor influencing the success of breastfeeding. Stress, excessive feeling of worry, unhappiness in the mother is instrumental in the success of exclusive breastfeeding ${ }^{[6]}$.

Lack of breastmilk production in in the first days of infant life should be anticipated since pregnancy through lactation counseling. But the dissemination of information among health workers and communities was also not optimal. Only about $60 \%$ of people know information about breastfeeding and only about $40 \%$ of trained health workers can provide breastfeeding counseling. So there needs to be a solution for incresing the breastmilk production and one of those solution are by used hypnobreastfeeding oxytocin massage $^{[7]}$.

Hypnobreastfeeding is a therapy given to patients with a combination of self hypnosis practices (self hypnosis) to help increase the milk production provided with guidance from the hypnotherapist to achieve deep relaxation ${ }^{[8]}$.while the Massage of oxytocin is a massage along the spine (vertebrae) to the fifth-sixth costae bone and is an attempt to stimulate the hormone prolactin and oxytocin after delivery.

\section{Methods}

Design: This research is Quasi-experimental studies with pre test and post test approach with control group design which was conducted in 13 villages in the working area of Bergas Public Health Center, Semarang regency on February 08 until February 22, 2017.

Population and sample: The population in this study were all postpartum mothers in Bergas PublicHealth Center working area and by using purposive technique sampling got 52 postpartum mothers as a sample.

Instrument: Instrument in this research was a Standard Operating Procedures (SOP) Massage Oxytocin and SOP hypnobreastfeeding while for measuring breastmilk volume was by using electric breast pump and measuring cup.

Intervention: sample was divided into 4 group, the first group was combination group who was given 2 times daily hypnobreastfeeding and oxytocin massage in the morning and afternoon with 20-30 minutes duration given for 4 days. The second group was given 2 times daily hypnobreastfeeding in the morning and afternoon with 20-30 minutes duration given for 4 days. The third group was given 2 times daily oxytocin massage with 15-20 minutes duration given for 4 days. And the fourth group (control group) was given standard breast treatment 2 times daily with 15 minutes durationfor 4 days. First, second and third group was given standard breast treatment before the intervention was done.After the intervention in the four groups performed, the measurement of breastmilk production by pumping breastmilk on both breasts of the mother when the breast has not been fed yet to the baby on day 2, 3, and 4 using the electric pump that is spectra 9 plus.

Data Analysis: In this study to compare the difference of breastmilk volume between 4 groups was using one way Anova test and repeated 


\section{JMSCR Vol||05||Issue||10||Page 28600-28604||October}

Anova was used to analyze the difference of breastmilk volume before and after treatment in each groups. And to assess the level of effectiveness of the four intervention was by Post Hoc Anova test

Ethical Consederation: This study has been approved by the ethics committee of Poltekkes
Kemenkes Semarang with No. 142 / KEPK / Poltekkes-SMG / EC / 2017 on The Effect of Hypnobreastfeeding and Oxytocin Massage on Breastmilk Production in Postpartum.

\section{Results}

Table 1 Univariat Analyzes by Age, Sleep Duration, Parity, Occupation, Education, and Anxiety

\begin{tabular}{|c|c|c|c|c|c|}
\hline Variable & Mean & $S D$ & Min & $\operatorname{Max}$ & Sig. \\
\hline \multicolumn{6}{|l|}{ Age (Years) } \\
\hline Combination & 32,23 & 2,006 & 28 & 35 & \multirow{4}{*}{$0,749 *$} \\
\hline Hypnobreatfeeding & 31,77 & 2,386 & 28 & 35 & \\
\hline Massage & 33,31 & 2,016 & 28 & 35 & \\
\hline Control & 32,08 & 2,060 & 28 & 35 & \\
\hline \multicolumn{6}{|l|}{$\begin{array}{l}\text { Sleep Duration } \\
\text { (Hours) }\end{array}$} \\
\hline Combination & 4,92 & 0,760 & 4 & 6 & \multirow{4}{*}{$0,490^{*}$} \\
\hline Hypnobreatfeeding & 5,15 & 0,801 & 4 & 6 & \\
\hline Massage & 5,54 & 0,660 & 4 & 6 & \\
\hline Control & 5,15 & 0,899 & 4 & 6 & \\
\hline \multirow[t]{2}{*}{ Parity } & \multicolumn{2}{|c|}{ II (Two) } & \multicolumn{2}{|c|}{ III (Three) } & \multirow{6}{*}{$0,136^{*}$} \\
\hline & $\mathbf{N}$ & $\%$ & $\mathbf{N}$ & $\%$ & \\
\hline Combination & 8 & 61,5 & 5 & 38,5 & \\
\hline Hypnobreatfeeding & 7 & 53,8 & 6 & 46,2 & \\
\hline Massage & 4 & 30,8 & 9 & 69,2 & \\
\hline Control & 10 & 76,9 & 3 & 23,1 & \\
\hline \multirow[t]{2}{*}{ Occupation } & \multicolumn{2}{|c|}{ Housewife } & \multicolumn{2}{|c|}{ Labour } & \\
\hline & $\mathbf{N}$ & $\%$ & $\mathbf{N}$ & $\%$ & \\
\hline Combination & 6 & 46,2 & 7 & 53,8 & \\
\hline Hypnobreatfeeding & 6 & 46,2 & 7 & 53,8 & $0,812 *$ \\
\hline Massage & 5 & 38,5 & 8 & 61,5 & \\
\hline Control & 8 & 61,5 & 5 & 38,5 & \\
\hline \multirow[t]{2}{*}{ Education } & \multicolumn{2}{|c|}{ Junior High School } & \multicolumn{2}{|c|}{ High School } & \\
\hline & $\mathbf{N}$ & $\%$ & $\mathbf{N}$ & $\%$ & \\
\hline Combination & 4 & 30,8 & 9 & 69,2 & \\
\hline Hypnobreatfeeding & 7 & 53,8 & 6 & 46,2 & $0,312 *$ \\
\hline Massage & 6 & 46,2 & 7 & 53,8 & \\
\hline Control & 4 & 30,8 & 9 & 69,2 & \\
\hline \multirow[t]{2}{*}{ Anxiety } & \multicolumn{2}{|c|}{ Mild } & \multicolumn{2}{|c|}{ Moderate } & \multirow{6}{*}{$0,136^{*}$} \\
\hline & $\mathbf{N}$ & $\%$ & $\mathbf{N}$ & $\%$ & \\
\hline Combination & 10 & 76,9 & 3 & 23,1 & \\
\hline Hypnobreatfeeding & 8 & 61,5 & 5 & 38,5 & \\
\hline Massage & 9 & 69,2 & 4 & 30,8 & \\
\hline Control & 7 & 53,8 & 6 & 46,2 & \\
\hline
\end{tabular}

*Homogenity test (levene's test)

Based on table 1 above, it was found that all variables (age, Sleep Duration, Parity, Occupation, Education and Anxiety) were have $\mathrm{p}$ value $>0,05$ there means there is no difference in variance between 4 groups in Age, Sleep Duration, Parity, Occupation, Education and Anxiety.
Table 2 Mean Differences of Breastmilk Production

\begin{tabular}{lccc}
\hline \multicolumn{1}{c}{ Groups } & Mean & SD & P value \\
\hline & & & \\
Combination & 77,44 & 9,54 & \\
Hypnobreastfeeding & 58,70 & 5,21 & $0,000^{*}$ \\
Oxytocin Massage & 51,60 & 6,55 & \\
Control & 40,41 & 6,03 & \\
\hline *one way anova & & &
\end{tabular}


Based on table 2, all of the groups have $p$ value $<0,05$ these indicate that all of the intervention significant difference between mean breastmilk production before and after interventions and by mean value, the Combination group that was given hypnobreastfeeding and oxytocin massage have the Biggest mean value which was 77,44 and the lowest group was the control group.

Table 3 Post Hoc of Breastmilk Production before and after interventions for each groups.

\begin{tabular}{|c|c|c|c|c|}
\hline \multirow[t]{2}{*}{ Groups } & \multirow[t]{2}{*}{$\begin{array}{c}\text { Mean } \\
\text { Difference }\end{array}$} & \multirow[t]{2}{*}{ Sig. } & \multicolumn{2}{|c|}{$\begin{array}{l}\text { 95\% CI for } \\
\text { Difference }\end{array}$} \\
\hline & & & $\begin{array}{l}\text { Lower } \\
\text { Bound }\end{array}$ & $\begin{array}{l}\text { Upper } \\
\text { Bound }\end{array}$ \\
\hline Combination & $77,449 *$ & $0,000 * *$ & 83,216 & 71,683 \\
\hline Hypnobreastfeeding & $58,705^{*}$ & $0,000 * *$ & 61,854 & 55,556 \\
\hline Oxytocin Massage & $51,602 *$ & $0,000 * *$ & 55,566 & 47,637 \\
\hline Control & $40,412 *$ & $0,000 * *$ & 44,059 & 36,764 \\
\hline
\end{tabular}

\section{*Post Hoc}

Based on table 3 , all of the groups have $p$ value $<0,05$ these indicate that all of the intervention significant difference between mean breastmilk production before and after interventions and based on mean difference, the Combination group that was given hypnobreastfeeding and oxytocin massage have the biggest mean which was indicate that hypnobreastfeeding and oxytocin massage was the effective intervention for increased breastmilk production.

\section{Discussion}

The results showed that combination of hypnobreastfeeding and oxytocin massage was the greatest intervention for increasing breastmilk production compare to other interventions. The oxytocin massage with hypnobreastfeeding combination is an action performed on breastfeeding mothers in the form of back massage using hypnotherapy in the form of positive suggestion, such as a suggestion about mother's belief about fluency of milk and increase milk production. Massage of oxytocin by using hypnobreastfeeding is done to provide comfort to the mother so that it will provide comfort also to the baby,therefore it will stimulate the production of oxytocin by the hypophysis gland that causes contraction of special cells that surround the aveoulusmamae and lactiferous ducts ${ }^{[9]}$. At the same time it stimulates the adenohifofise gland so that prolactin enters the circulatory system and causes acinus cells in the alveoli to produce milk or often called reflex prolactin ${ }^{[10]}$.

In hypnobreastfeeding, the postpartum is naturally promoted to calm down and instill positive programs/intentions/suggestions during breastfeeding until the postpartum period ends. The positive suggestion implanted will be channeled to the brainstem towards the thalamus sensor, in the thalamus the stimulus is formatted according to the language of the brain. The stimulus is transmitted to the amygdala, hippocampus and cerebral cortex. In cerebral cortex occurs the process of sensory associations in which stimuli are analyzed, understood to be composed into something so real that the brain recognizes the object and meaning of its presence. The hippocampus acts as a determinant or judgment, the preferred things are considered important signals by the hippocampus so that it is processed into memory ${ }^{[11]}$. It can thus be concluded that the puerperal mother following the hypnobreastfeeding technique always gets positive suggestions that enter her mind. Human thoughts and behavior are dominated by the subconscious mind while the conscious mind in human selfcontrol is only $12 \%$, therefore it is important to inculcate the positive in the mind ${ }^{[11,12]}$.

Meanwhile the oxytocin massage is more effective when done 2 times and this is have been approved by a researcher ${ }^{[13]}$. Oxytocin massage and hypnobreastfeeding combination activates the work of the nervous system and hormonal system in the mother's body. Active oxytocin hormone stimulates prolactin hormone to increase. with the calm and comfortable conditions that mom feel makes the mother more relaxed and the more milk production produced by the mother. The volume of breastmilk released by the breast glands may differ based on the factors that affect it ${ }^{[14]}$. 
In the first days of the baby's birth, if the nipple suction is adequate, breastmilk production will be gradually generated $10-100 \mathrm{ml}$ of milk, and will be optimal to $700-800 \mathrm{ml}$ on $10-14$ day. breastmilk production will begin to decrease to $500-700 \mathrm{ml} /$ day after the first 6 months ${ }^{[13]}$.

However the limitations in this study are on Measuring milk production that is not done in every hour but only 2 times in 24 hours so that the measurement results become less significant.

\section{Conclussion}

Hypnobreastfeeding and Oxytocin Massage can significantly increased breastmilk production on Postpartum mother, while the combination beetwen hypnobreastfeeding and oxytocin massage showed the greatest results on increasing breastmilk procuction compare to other interventions.

\section{References}

1. Departemen Kesehatan Republik Indonesia. Laporan Hasil Riset Kesehatan Dasar Indonesia (Riskesdas). 2013

2. SDKI 2012. Kemenkes RI. Survey Demografidan Kesehatan Indonesia. Jakarta : Kemenkes RI. 2012

3. Chertok, I,R and ShohamVardi, I. Infant hospitalization and breasfeeding post caesarean section, British Journal of Nursing. 2008

4. Cox, S. Breastfeeding with confidence: Panduan untuk belajar menyusui dengan percayadiri (Gracinia, Penerjemah) Jakarta: Gra,media.2006

5. Blair. T. Sucking of lactation mother. Article.

http://www.ncbi.nlm_nih.goy?entrez?quor y.fcgi?db=pubmed\&cdm=search\&zitol=pu bmedabstract,diperolehtanggal 13 Januari 2017.

6. Guyton dan Hall. Fisiologi Kedokteran, Buku Ajar (Setiawan, Dkk, Penerjemah). Jakarta, EGC. 2007: 75-89
7. Arifin, Siregar. Pemberian ASI Eksklusifdan Faktor-faktor yang Mempengaruhinya. Jurnal USU. 2005

8. Unvas Kerstin- Mober. Oxytocin May Mediate The Benefits Of Positive Sicial Interactin And Emotions. Sweeden. 2008

9. Colin.W.B \& Scott J.A. Breastfeeding: reason for starting, reasons for stopping, and problem along the way. Australia: School of Public Health.2012

10. Bobak, Lowdermik, Jesen. Keperawatan maternitas. Jakarta: EGC.2005: 45-50.

11. Yurundra,Yan. Modulpelatihan Advance hypnotherapy, IBH. Jakarta .2015tian Klinis. Edisi 3 Cetakan Kedua. 2010: 3745

12. Ellias., Hipnosis \& Hipnoterapi, Transpersonal / NLP, Pustaka Pelajar, Jogjakarta: 2009. 55-60

13. Biancuzzo, M. Breastfeeding the new born :clinical strategies for nurse. St.Lois: Mosby. 2003. 110-115

14. Handayani \& Wulandari. Asuhan kebidanan ibu masa nifas. Yogyakarta: gosyen Publishing. 2011: 34-47

15. Wiji. Rizki.N. ASI danpanduanibu menyusui.Jakarta.2013 : 38-40. 